\title{
Second and Third Thoughts on Privatisation in Indonesia
}

\author{
Ross H. McLeod
}

$\mathrm{I}$

ndonesia's economic policies began to become much more market oriented during the 1980s. Various policy reforms were implemented, notably in the field of international trade (Fane and Condon, 1996). In addition, there came to be a new emphasis on privatisation, although this was nearly all talk and no action (Hill, 2000:103-5). In 1989 the then Finance Minister announced that 52 state-owned enterprises (SOEs) would be listed on the Jakarta Stock Exchange between 1990 and 1992 (Habir, 1990:101); in the event, almost none were. In 1993, the then Minister for Research and Technology, B. J. Habibie, claimed that a similar number could be sold quickly (McLeod, 1993:7); again, almost nothing came of this. Nevertheless, although there was a conspicuous lack of progress with privatisation as normally conceived, there are several examples of effective privatisation, provided this term is interpreted sufficiently broadly.

\section{Approaches to Privatisation}

In the conventional sense, 'privatisation' refers to the sale of SOEs to the private sector. The Indonesian government owns a wide range of enterprises, including electricity, water supply, transportation, telecommunications and construction companies, mining and manufacturing firms, plantations, banks, insurers, importers, retailers and hotels. There is, therefore, much scope for privatisation by way of divestment of SOEs.

In a broader sense, privatisation can be thought of as encouraging relatively greater private sector involvement in parts of the economy relative to the public sector. By definition, the divestment of SOEs results in a larger share of the market in question being supplied by the private sector. But this can also be achieved by encouraging the involvement of, and competition from, private enterprises in sectors where state-owned firms exist. There was in fact quite considerable privatisation in Indonesia in this broader sense in the late 1980s and the 1990s. We shall consider examples from three different industries in this paper: banking, civil aviation and electricity.

\section{The Banking Sector}

Commencing in 1982 the government began to deregulate the banking sector, which was at that time heavily dominated by seven large state institutions: five commercial banks, a savings bank and a development bank (McLeod, 1999). 
There were many more privately owned banks, but in aggregate they accounted for only seven per cent of total bank assets. In the early phases of deregulation the government abolished its practice of trying to impose ceilings on the growth of each bank's assets, which had held back the growth of the private banks. In the later phase, commencing in 1988, the government abolished barriers to entry to banking that for many years had prevented the establishment of new banks. In addition, it removed bureaucratic obstacles to the expansion of the banks' branch networks.

The impact was dramatic (Table 1). The number of private banks increased rapidly, and the number of bank branches even more so. Other indicators, such as the number of savings bank accounts and the total amount of deposits of all kinds grew extremely rapidly as banking became much more accessible to the general population, and as banks offered attractive interest rates and other incentives to their customers. Previously many businesses, and most individuals, had no bank deposits at all. Although the existing state banks also expanded their branch networks and became somewhat more customer oriented, the net result was that the market share of the private banks grew dramatically at the expense of the state banks. In other words, the industry as a whole moved in the general direction of privatisation, even though no state banks were sold. In a single instance, a minority share ( 25 per cent) of Bank BNI, one of the state banks, was sold to the general public (in 1996). The bank was publicly listed, but still continued to be thought of, and to behave, as a state-owned bank.

Table 1: Impact of Deregulation on Indonesia's Private Banks

\begin{tabular}{|lcc|}
\hline & Dec 1988 & Jun 1997 \\
\hline Number & 63 & 160 \\
Branches & 574 & 4,267 \\
Savings accounts (million) & 2.6 & 17.4 \\
Deposits (Rp trillion) & 11 & 183 \\
Share of total assets (\%) & 24 & 54 \\
(State banks' share of total assets, \%) $^{\mathrm{a}}$ & 71 & 35 \\
\hline
\end{tabular}

Note a: The remaining market share was held mainly by local branches or subsidiary joint ventures of foreign banks.

\section{Civil Aviation}

The case of the civil aviation industry is analogous to that of the banking sector. For decades civil aviation was dominated by the state airline, Garuda. A number of small airlines competed on a few domestic routes, but Garuda enjoyed a near monopoly position by virtue of being the only airline permitted to operate jet 
aircraft. This policy was dropped in the early 1990s, at the same time that a controlling private sector interest was established in a small airline, Sempati Air, previously owned by the military. The new policy allowed Sempati to compete effectively with the poorly managed Garuda, just as banking deregulation allowed private banks to compete effectively with the state banks. This new airline quickly established a high profile, and injected a hitherto unknown emphasis on concern for the travelling public. It introduced lottery prizes for passengers, compensated them if departures were late, simplified and speeded up the process of making reservations, and so on. The private sector market share increased rapidly as new domestic routes were added, eventually to be followed by the introduction of a few international routes. The further benefit was to put pressure on Garuda to improve the quality of its own service.

\section{The Electricity Sector}

The sale of electricity has always been monopolised by the state electricity company, PLN (Perusahaan Listrik Negara). It should be noted, however, that many of the larger consumers of electricity have their own generation capacity, because PLN has not always had a good reputation for reliability, and it has often been thought more economic to be self-reliant than to run the risk of incurring the cost of power blackouts (McCawley, 1970). In 1990, however, the government announced its intention to encourage private sector involvement in the power generation component of this sector. It contracted with a number of private consortia on a build, own and operate basis to construct some 26 new plants to supply electricity to the national grid. As a result of this, perhaps a third of national power generating capacity (excluding generation for own use) is now in the hands of the private sector. Thus, although consumers of electricity still can deal only with PLN as supplier, to a significant extent the ultimate source is now the private sector.

\section{The Crisis of 1997-98 and Consequent Problems with Privatisation}

Superficially, at least, Indonesia seemed to be privatising various parts of the economy very successfully, even if the government made very little progress by way of enterprise divestment. But the process went horribly wrong when the economy went into crisis, along with several other Asian countries, beginning in 1997 (McLeod, 1998).

The Asian crisis brought an abrupt end to the rapid growth of the private sector's market share in banking. The unexpected float and large depreciation of the Thai baht in July 1997 resulted in a loss of confidence in the rupiah, which lost 24 per cent of its value over the next two months alone. This had drastic implications for the corporate sector, which had faced an exchange rate risk by virtue of having borrowed heavily in dollars rather than rupiah, often in order to invest in sectors producing non-tradables. In turn, many of these dollar loans had been provided by domestic banks, which quickly came under pressure in the form 
of large scale withdrawals of deposits. Before long the central bank began to operate as lender of last resort, providing emergency liquidity to banks whose funds were being drained (Enoch et al., 2001:32). This was not enough to stop the run on deposits, however, and the government eventually issued a guarantee of the banks' liabilities.

Last resort lending is not the appropriate policy when banks are clearly insolvent, rather than merely illiquid, of course, and all that was achieved by it was to delay the inevitable - and to make the eventual losses even greater. Fane and McLeod (forthcoming) estimated the fiscal cost of the claims against the government's guarantee of bank liabilities to be of the order of 40 per cent of GDP; recent developments suggest that this is likely to be an underestimate.

Sempati Air also became bankrupt during the crisis, with debts vastly in excess of its assets. An important explanation for this is that, since most of its sales were in the domestic market, whereas three of its major cost items - aircraft lease payments, debt service and aviation fuel - were dollar-denominated, it suffered greatly as a result of depreciation of the rupiah, just like many other firms producing non-tradables. Unable to increase its airfares sufficiently - not least because government pressure on its major competitor, Garuda, prevented the latter from raising its fares as well - Sempati quickly found itself facing large negative cash flows that soon caused it to collapse (while government backing of Garuda allowed it to avoid a similar fate). Among its very large debts were unpaid bills for the supply of aviation fuel by Pertamina, the government owned petroleum monopoly, and for the rental of airport facilities of the state-owned company, Angkasa Pura. As a group, the now defunct Sempati Air plus two of its principal owners, the Humpuss and Nusamba conglomerates, is among the largest defaulters on loans from the state banks.

The experiment with privatisation in the electricity industry has been similarly disastrous, resulting in huge losses to the government - albeit much smaller than those from the banking system. In this case the losses are a direct consequence of the nature of the contracts that governed the supply of power by private generators to PLN. These contracts had two crucially important features.

First, the supply price for electricity was denominated in US dollars. This meant that by 1998, after the rupiah price of US dollars had risen by a factor of four or five, the rupiah price of power supplied to PLN had risen in direct proportion. But the political realities were such that the government felt unable to allow PLN to increase its prices to consumers (denominated in rupiah) commensurately. Thus PLN immediately began to lose on every unit of electricity it purchased from the private power companies.

Second, the contracts required PLN to 'take or pay'. That is, once the private companies had installed a certain amount of productive capacity, PLN was obliged to purchase all of their output, or to pay an equivalent amount if it purchased smaller quantities. In the context of the unfolding economic crisis, many large factories and other users of electricity were cutting back their own output, and so their demand for electricity fell accordingly. This further reduced PLN's revenues relative to the amounts it was obliged to pay to the private producers. The overall 
result has been an enormous drain on the budget, to which PLN's profits had been a significant contributor in better times.

\section{Ambivalent Ongoing Support for Privatisation}

In short, although previously these three examples of privatisation had seemed quite successful, with the advent of the crisis they ultimately proved to be very costly failures. Nevertheless, the government is still committed to ongoing privatisation, especially as this is one feature of economic policy demanded by the IMF in return for its continued crisis-related financial support.

It is worth noting in passing that there has been some ambivalence on this point, especially in relation to the banking system. When it became clear that many of the banks - and all of the major banks - were insolvent, the government decided, in consultation with the IMF and the World Bank, ${ }^{1}$ to:

- take over, or at least take a majority shareholding in, many of the large private banks that had failed, and recapitalise them

- transfer the deposit liabilities of banks that were closed to state banks

- $\quad$ set up what was in effect a new state-owned holding company, the Indonesian Bank Restructuring Agency (IBRA), to which were transferred all of the assets of banks that had been closed, along with the worst of all the nonperforming loans of the state banks and the private banks that had been recapitalised.

The intention, nevertheless, was for these arrangements to be temporary. Nationalised banks were to be privatised as soon as possible; newly acquired government stakes in private banks were to be divested as soon as possible; the state banks themselves were soon to be privatised; and IBRA was to have a limited life of only five years during which it would sell off all of the assets it had acquired and then be wound up.

There has been a disappointing lack of progress, however. All the state banks are still owned by the government, and their relative importance has grown significantly by virtue of the large volume of deposits transferred to them from failed private banks. Only one of the nationalised banks has been divested.

This lack of progress is partly attributable to policy makers having second thoughts on privatisation: given that the 'privatisation' that had been achieved prior to the crisis has turned out to be a failure, it now appears to many that privatisation is not so desirable after all. To argue against privatisation for this reason, however, is conveniently to ignore the fact that state enterprises have fared no better than private during the crisis, and that their survival is attributable to the perceived willingness of the government to repay their debts regardless of whether they are insolvent. For example, the state banks have also amassed enormous

1 A detailed record of the evolution of policy during this period is contained in (Enoch et al., 2001:26-40). 
$\operatorname{losses}^{2}$ - as they had done on many occasions prior to the present crisis (McLeod, 1999:281) — as has the state-owned airline, Garuda. Moreover, the state enterprises in general have always generated little by way of profit for the government - or have required large subsidies to keep them going (Hill, 2000:105-7).

\section{Third Thoughts: The True Rationale for Privatisation}

Privatisation in the conventional sense is undeniably important in present circumstances from the point of view of providing the cash flows needed to maintain the government's spending programmes. The government now faces the huge burden of servicing bonds it had to inject into the banks to make good their losses; at the same time, additional borrowing is not an option, and the scope for increasing tax revenues in the short term is very limited. But cash generation is not the real rationale for privatisation. After all, the only sound reason for converting earning assets to cash is if their return is lower than the opportunity cost of continuing to hold them. In the present context, a lower bound for the opportunity cost is indicated by the interest rates paid on bank recapitalisation bonds, which could be retired using the proceeds from privatisation. The true opportunity cost of funds tied up in state ownership of enterprises is somewhat higher than this, since the rates on these bonds are artificially low, having been set unilaterally by the government (McLeod, 2000:28). If private sector owners are more efficient managers, the sale value of the enterprise in question will be greater than the present value of future returns likely to be earned with the government as manager.

Thus the fundamental economic argument in favour of privatisation still stands. The core of this argument is that enterprises will be managed better when managers have their own funds at risk, or are appointed by shareholders with a significant stake in the company in question. The incentives for sound management of state-owned enterprises in Indonesia are largely non-existent: the rule of law is very weak, and accountability of the government through the political processes - given an unsophisticated electorate unused to democracy is also lacking.

Unfortunately, however, this argument sits uncomfortably beside the reality of the failed experiments with privatisation described above. Evidently it is necessary to think more carefully about the process, and to ensure that the way in which it is approached is consistent with this core argument. We need to analyse Indonesia's experiments with privatisation more carefully. It is not enough to observe that they have failed; it is necessary to explain why they did so.

2 Indeed, Fane and McLeod (forthcoming) argue that the state banks' losses per unit of pre-crisis customers' deposits were considerably higher than those of the private banks. 


\section{Analysing Indonesia's Approach to Privatisation}

\section{Banking: partial divestment of a state bank}

It was mentioned briefly above that, of the seven state banks existing prior to the crisis, the government had only divested a small minority shareholding in one of them, Bank BNI. Little, if anything, was achieved by this. The government was not seriously in need of additional cash at that time, and no single private shareholder acquired a large enough stake to be able to exert any significant influence on the policies and strategies of the bank. Presumably the government obtained a price per share from the divestment lower than its potential, since buyers would have realised that the introduction of new management capable of extracting greater value from the bank's assets was not in prospect. Bank BNI gained some notoriety during the crisis by virtue of having provided well over \$US1 billion of loans to a single conglomerate, Texmaco, which is now by far the single largest debtor to IBRA by virtue of defaulting on these loans (Fane, 2000a:29-30). It was revealed in 2000 by the then Minister for State Enterprises that these loans had been provided by instruction of the former president, Soeharto. In other words, having a significant but fragmented minority private sector shareholding in the bank did nothing to offset the debilitating influence of the politically powerful.

It is clear what went wrong in this example of 'privatisation'. Partial divestment of the government's shares did not result in any private owner having a sufficiently large stake in the bank to provide the incentive and the ability to exercise strong influence on its management. The managers of the bank continued to have weak incentives to strive for high profits relative to their incentives to act in the interests of other parties such as political patrons, favoured borrowers, friends and relatives.

\section{Banking: private sector expansion}

In the case of privatisation of the banking sector by allowing the private sector to expand its market share at the expense of state banks, the explanation for the unsatisfactory outcome of the experiment is also closely related to the failure to ensure that the approach was consistent with the core argument in favour of privatisation. Specifically, the government failed to ensure that the owners of the private banks had significant amounts of their own wealth at risk. There were two reasons for this.

First, the prudential regulations called for banks to observe a minimum capital adequacy ratio (CAR, the ratio of capital to risk weighted assets) of only 89 per cent. ${ }^{3}$ This reflects an extremely high gearing ratio (that is, ratio of debt to equity) relative to the norms of the corporate sector outside banking. The only

3 The minimum CAR was in the process of being raised in stages from eight per cent to 12 per cent. It became nine per cent in September 1997, just as the crisis was getting under way. 
obvious explanation for creditors of banks — primarily, their depositors — being willing to accept such a small level of equity to protect themselves against potential losses incurred by the banks is that there is a perception that the government will step in to provide such protection if necessary. When the crisis struck this is precisely what it did, despite frequent denials previously that it provided any kind of guarantee of the safety of bank deposits.

As we have seen, the banks made skilful use of this perception of an implicit government guarantee by actively marketing their deposit products, opening many new branches and offering high interest rates and other benefits such as lottery prizes. The implicit government guarantee amounted to a subsidy, and the more deposits that could be mobilised, the greater its total value. In turn, much of the subsidy found its way to borrowers, who were able to borrow at lower rates than if it had not existed.

Second, the government permitted banks to lend to affiliated parties roughly speaking, to companies owned by the same people. The prudential regulations attempted to limit this practice by imposing a ceiling on loans to affiliates as a proportion of banks' capital. The constraint was lax in itself by international standards, but in any case, banks flouted these lending limits with impunity: the central bank, in its capacity as prudential regulator, seemingly did nothing to enforce its own regulation.

The effect of banks lending to their own affiliates is to reduce the amount of funds of the owner genuinely at risk. Suppose that an owner subscribes $\$ 1$ million as equity in the bank, but then makes a loan to himself of $\$ 1$ million. If he fails to repay the loan there is then effectively no equity cushion for the benefit of the bank's creditors if it gets into trouble. If the bank were to be wound up, the depositors would need to try to recover the loan from the owner through the courts, but this may be exceedingly difficult — especially if the loan documentation is inadequate and collateral of low value or non-existent. In a country in which the legal system is inefficient, lacking in competence, and highly corrupt, the chance of success would be negligible. The owner could expect to escape with his million dollars intact and, given the extreme political pressure on the government to protect depositors, the effect would be to shift the banks' losses to taxpayers. This precisely describes what has happened in countless cases in Indonesia during the crisis.

\section{Civil Aviation}

Disparate though the two sectors may be, the failure of privatisation in civil aviation occurred for much the same reason as that in banking - namely, the failure to ensure that the private sector owners of Sempati had a significant amount of their own wealth at risk. In this case there also appears to have been what amounted to an implicit government guarantee that allowed the company to build up large and practically unsecured debts to its major suppliers and 
financiers. ${ }^{4}$ Alternatively, it could be said that the losses to the state in this case derived from the poor business practices of various state-owned enterprises: the state banks that lent to Sempati; the state petroleum company that supplied it with fuel on credit; and the state-owned airports that failed to collect rent payments from it. In this sense, the failure of civil aviation privatisation stems not from the new private sector competitor, but from grossly deficient management (no doubt the result of political interference) of state enterprises with which it had significant business relationships.

\section{Electricity sector}

Although the task of power generation was partly turned over to the private sector, again this was not done in a manner consistent with the core argument in favour of privatisation. The private sector members of the various consortia that constructed power generation plants did have large amounts of their own funds at risk, but two of the major risks themselves were shifted to the government - consistent with the notion of 'privatisation of profits and socialisation of losses'. First, there was the risk that the demand for power from each new plant would be significantly less than its supply capacity, either because aggregate demand for electricity had been overestimated, or because of the large number of new generators being constructed. By accepting 'take or pay' contracts in its negotiations with the new private operators, the government allowed this risk to be shifted to itself. Second, there was the exchange rate risk, reflecting the possibility that the government might not always persevere with its policy of slowly but steadily depreciating the rupiah against the US dollar (McLeod, 1997:33). By virtue of PLN's acceptance of dollar-denominated prices for electricity, this risk was also shifted to the government; the outcome of negotiations over contract details no doubt had much to do with the identity of the domestic partners in each of the consortia, all of whom were either relatives or cronies of the president (Thirwell, 2001). In short, the requirement that the risks of the business in question would be carried by its private sector owners was violated in these two very important respects.

One of the principal reasons why government-owned businesses make losses is that they are always under political pressure to hold their selling prices down, even though their costs may be rising. There are also pressures to hold buying prices (such as wages) up, and to extend excessive amounts of credit for lengthy terms and without adequate security. In the private sector, firms are generally free to put up their prices and, although this may meet with opposition from their customers, there is little to fear except if the price increases are intended to offset inefficiency or to earn excessive profits. In these cases the firms can expect to lose market share to more efficient and less avaricious competitors, but private sector firms are far less vulnerable than SOEs to interference from politicians

4 In Indonesia's weak and corrupt legal environment it has been common for borrowers to divert cash revenues to related companies in such a manner as to be unrecoverable by creditors. It is noteworthy that Sempati was declared bankrupt at its own request, not that of its creditors. 
worried about being voted out of office if prices increase. Thus privatisation of power generation in Indonesia can be said to have failed because the approach followed did nothing to deal with this intrusion of politics into commercial decision-making, resulting in the transfer of financial risks from the private producers to the government through PLN.

\section{Making Privatisation Work}

\section{Banking}

The government's stated intention is to return ownership of the wholly or largely nationalised former private banks to the private sector, and to sell off the state banks. Obviously it is important that the previous mistakes with privatisation are not repeated. Action is required on several fronts to avoid the kinds of outcomes described above, by ensuring that private bank owners have significant amounts of their own capital at risk.

First, much higher standards for capital adequacy need to be set. It is arguable that the CAR of eight per cent prescribed in the international convention known as the Basle Accord (Basle Committee on Banking Supervision, 1988) is too low, even in developed economies. An important purpose of capital, or equity, in all businesses is to provide a cushion of safety to creditors. Clearly this cushion needs to be larger when the risks are relatively large, which is certainly the case in Indonesia (and probably in developing countries in general), where political stability cannot be taken for granted, the legal system is exceedingly weak, and the economy is vulnerable to negative shocks of various kinds. On this basis, Fane (2000b:127-30) argues in favour of a CAR of at least 16 per cent for economies similar to Indonesia.

Second, much greater care needs to be taken in measuring and defining capital for the purpose of calculating the CAR. A more realistic approach is called for, in which assets are marked to market frequently, and adequate provisions for loan losses are created in timely fashion whenever there are indications that particular loans may not be repaid in full. In addition, capital should be defined to exclude the value of loans or any other kind of exposure of the bank to affiliated companies. In the previous example of a bank with equity of $\$ 1$ million that lent $\$ 1$ million to a firm controlled by its owner, the bank's capital would be recorded as zero for regulatory purposes, because the $\$ 1$ million loan to its owner would be offset against the $\$ 1$ million of equity. This would have the desirable impact of removing the incentive to set up banks for the main purpose of obtaining cheap finance for affiliated companies by exploiting the implicit government guarantee of bank safety.

Third, the prudential regulator should be far more active in requiring corrective action from banks whose capital adequacy falls below the specified minimum. There should be very little regulatory forbearance: owners should be required to repair any capital deficiency without delay. If they failed to do so the bank should be taken out of their control and sold to another party, who would be 
required either to build up the bank's capital immediately or to liquidate it. If the bank continued to operate, the original owners should receive the purchase price paid by the new owner. If it were liquidated, they should receive nothing (Fane and McLeod, 2002).

Fourth, given the apparent impossibility of persuading the general public that the government will not make good their deposits in cases where banks fail, it would also seem sensible to implement a system of deposit insurance, provided it is operated on genuine market principles. Banks would need to pay insurance premia that reflected the insuring institution's assessment of the risk of failure of each bank: the insurer should not be subsidised in any way by the government. Under such arrangements it could be expected that insurance premia would be inversely related to capital adequacy: the higher the bank's capital relative to risk assets, the lower the risk to the insurer, and the lower the insurance premium. This would provide a market-based incentive to maintain higher CARs, rather than relying purely on enforcement by the prudential regulator. Indeed, with deposit insurance it would be sensible for the insurer to become, in effect, the prudential regulator, since it would have a relatively strong incentive to enforce prudential regulations: these would simply become part of the terms and conditions of the insurance contract.

There is no reason why the deposit insurance institution or institutions should be owned by the government. Indeed, given Indonesia's long history of poor management of state-owned financial institutions (not least as a result of heavy political interference) there is a strong argument for requiring them to be owned by international entities of strong repute, or simply to require the banks to purchase insurance from such entities abroad (Schmulow, forthcoming). In this manner, the government could avoid almost the entire need to be involved with the prudential regulation of banks, and it could almost entirely remove the risk of having to bail out banks' depositors again: it could simply require each bank to be properly insured by an approved foreign insurer (and draw up a list of approved institutions for that purpose). This would be a genuinely market-oriented approach to privatisation of the banking system, similar to the recent emergence of insured investment funds in the Australian capital market.

\section{Civil aviation}

The first best policy here would be for the government to fully divest itself of Garuda and to open up the industry to new competitors, including foreign airlines; there is no sound justification for having a government-owned airline. If the government thinks it necessary to have aircraft serving particular routes that would not be commercially viable it can easily provide an explicit subsidy to a private airline to do so - and justify this policy to the electorate. In addition, it will be essential to ensure that other government entities provide no hidden subsidies, and avoid significant financial exposures, to private airlines. For example, Pertamina should insist on some arrangement such as regular weekly payments for fuel not more than, say, one month in arrears; likewise the airport management company 
should insist on payment of rent in advance for premises and other facilities on, say, a monthly basis. (Better still, Pertamina and Angkasa Pura should also be divested. And if the plan to fully privatise the banking system comes to pass, then of course there will be no possibility of loan defaults by airlines at government banks.)

\section{Electricity}

A range of issues relating to future private sector involvement in the electricity sector need to be addressed if this is to be successful. The most immediate question is whether there is really an actual or incipient shortage of power generation capacity, as has been suggested often in recent times (McBeth, 2001). This is such a marked reversal from the story early in the crisis - when the major concern was with excess generating capacity after dramatic expansion of private facilities - that it seems more likely a reflection of artificially boosted demand resulting from a significant reduction in the real price of power to consumers (because of the government's unwillingness to raise prices in line with cost increases). If this is the case, the appropriate policy change is to adjust prices upward immediately in order to reflect the real cost of power production.

A second desirable change in relation to electricity generation would be for PLN's own existing production capacity to be sold to the private sector. Just as with banking and civil aviation, there is no sound reason to have a state-owned firm competing with private firms in power generation. In the course of divesting existing generators the government would need to come to grips with the appropriate form of contracts for the purchase of electricity by PLN. It is beyond the scope of this paper to canvass the wide range of possibilities (which also encompass divestment of the national grid and handing over the retailing function to the private sector $)^{5}$; suffice it to say that a major objective should be to ensure that the commercial risks of producing power are borne by the suppliers.

One benefit of divesting existing plants (through an open tendering process) is that this would reveal a reasonable supply price, or set of prices, for electricity. This could provide a basis for renegotiation of the contracts with existing private producers. These contracts not only shift major commercial risks to the government, but also specify prices well in excess of those that can be observed in other markets, reflecting the failure of the then government to ensure competitive tendering for the right to become a supplier to PLN and, related to this, the presence of Soeharto cronies and family members in all the joint venture consortia involved (Bosshard, 2000). The present government has already found that attempting to renegotiate these essentially corrupt contracts is fraught with danger, as the foreign partners are sufficiently influential to be able to rely on the support of their own, very powerful, governments in the US, Japan, Germany and the UK (Murphy, 1999). Nevertheless, its political position will be considerably

5 PLN has already talked of moving in these directions (Motoyama and Widagdo, 1999:10-11), though its plans seem naively optimistic given Indonesia's lack of achievement hitherto with privatisation. 
strengthened if it can present strong evidence that the existing contracts are grossly overpriced.

\section{Conclusions}

The divestment of state enterprises is not the only way to privatise industries. In Indonesia, privatisation has involved processes by which private sector involvement increases significantly without very much state enterprise divestment, despite the wide scope for it and despite the stated intention of successive governments to undertake such divestment. Considerable gains can be achieved by encouraging private sector involvement in this manner, whereas achieving similar gains simply by transferring ownership of existing state enterprises to private owners might face significant political obstacles.

Nevertheless, the experience of the last few years has shown that the devil is in the detail so far as privatisation is concerned: there are very significant dangers from privatisation, of whatever kind, if the core rationale for it is not kept clearly in mind. Specifically, the private sector is not necessarily more likely than the public sector to ensure that the enterprise is managed well unless the owners have a significant amount of their own funds at risk, and unless the major risks of the enterprise remain with its owners rather than being transferred back to the government in some manner. In short, Indonesia's second thoughts on privatisation are well justified. Nevertheless, the correct conclusion to be drawn from recent experience is not that privatisation should be abandoned, but that implementation in a manner consistent with its fundamental rationale is essential.

\section{References}

Basle Committee on Banking Supervision (1988), International Convergence of Capital Measurement and Capital Standards, Basle, http://www.bis.org/publ/bcbs04a.htm.

Bosshard, P. (2000), 'Publicly Guaranteed Corruption: Corrupt Power Projects and the Responsibility of Export Credit Agencies in Indonesia', http://www.ecawatch.org/bosshard.html.

Enoch, C., B. Baldwin, O. Frécaut and A. Kovanen (2001), "Indonesia: Anatomy of a Banking Crisis Two Years of Living Dangerously 1997-99." IMF Working Paper $\mathrm{WP} / 01 / 52$.

Fane, G. (2000a), 'Survey of Recent Developments', Bulletin of Indonesian Economic Studies 36(1):13-44.

Fane, G. (2000b), Capital Mobility, Exchange Rates and Economic Crises, Edward Elgar, Cheltenham, UK and Northampton, USA.

Fane, G. and T. Condon (1996), 'Trade Reform in Indonesia, 1987-95', Bulletin of Indonesian Economic Studies 32(3):33-54. 
Fane, G. and R. McLeod (forthcoming), 'Banking Collapse and Restructuring in Indonesia, 1997-2001', Cato Journal.

Habir, A. (1990), 'State Enterprises', in Hal Hill and Terry Hull (eds), Indonesia Assessment 1990, Australian National University, Canberra.

Hill, H. (2000), The Indonesian Economy, $2^{\text {nd }}$ edition, Cambridge University Press, Cambridge.

McCawley, P. (1970), 'The Price of Electricity', Bulletin of Indonesian Economic Studies 6(3):61-86.

McLeod, R. (1993), 'Survey of Recent Developments', Bulletin of Indonesian Economic Studies 29(2):3-42.

McLeod, R. (1997), 'Policy Conflicts in Indonesia: The Impact of the Current Account Deficit Target on Growth, Equity and Stability', ASEAN Economic Bulletin 14(1), July, 32-45.

McLeod, R. (1998), 'Indonesia', pp 31-48 in R. McLeod and R. Garnaut (eds), East Asia in Crisis: From Being a Miracle to Needing One?, Routledge, London and New York,.

McLeod, R. (1999), 'Control and Competition: Banking Deregulation and Re-regulation in Indonesia', Journal of the Asia Pacific Economy 4(2):258-97.

McLeod, R. (2000), 'Survey of Recent Developments', Bulletin of Indonesian Economic Studies 36(2):3-38.

Motoyama, H. and N. Widagdo (1999), Power restructuring in Indonesia: A preliminary study for advocacy purposes, Friends of the Earth-Japan and Bank Information Center, USA, http://www.bicusa.org/asia/indopower.htm.

Murphy, D. (1999), 'Trouble on the Grid', Far Eastern Economic Review 21 October.

Schmulow, A. (forthcoming), 'Problems of Prudential Regulatory Enforcement in the Indonesian Banking Sector', PhD dissertation, University of Melbourne.

Thirwell, M. (2001), 'Indonesia's Looming Power Crisis', Export Finance and Insurance Corporation, press release, 31 January.

The author is grateful for helpful comments by two anonymous referees. 